\title{
IS ELECTRONIC VOTING A PANACEA FOR LOW ELECTION TURNOUT? \\ EXAMPLES OF ESTONIAN E-ELECTIONS AND SWISS E-REFERENDUMS
}

\author{
by Magdalena Musiat-Karg
}

One of the most apparent signs of the crisis of the democratic system is a systematically decreasing turnout level in national and supranational elections and referenda. In reports and analyses concerning the level of political participation, experts more and more frequently notice a decreasing tendency of the citizen's involvement in numerous types of elections. As Ola Pettersson points out, "according to the sources, less and less citizens appear at the ballot boxes"'. Jacek Raciborski indicates that one of the most significant consequences of the low citizen's participation at the election procedures is the considerable legitimacy deficit ${ }^{2}$.

A number of countries attempt to prevent these phenomena from happening by undertaking various actions aimed at increasing the level of citizens' involvement in political life (notably by increasing their participation in elections). That would influence the growth of the legitimacy level

1 O. Pettersson, Rola instytucji publicznych i organizacji pozarządowych w przekazywaniu obywatelom informacji o wyborach - przykłady działań z różnych krajów, International IDEA, text prepared for seminar: „Jak skutecznie informować obywateli o wyborach?", Warszawa, 19 June 2009, p. 3.

2 J.J. Wiatr, J. Raciborski, J. Bartkowski, B. Frątczak-Rudnicka, J. Kilias, Demokracja Polska 1989-2003, Warszawa 2003, p. 208. 
of the undertaken political decisions. It is worth noticing, that apart from the commonly used ways of increasing election attendance (such as correspondence voting, mobile ballot boxes), over the last few years politicians in many countries have had numerous discussions aimed at the implementation of electronic voting (e-voting). Its followers claim that thanks to e-voting, election and referenda turnout may be increased, as this method enables disabled people and people who are abroad to take part in elections. Furthermore, a considerable advantage of e voting, compared to traditional voting in polling stations is of greater convenience than the former.

The aim of the following text is to attempt to provide an answer to the question whether electronic voting can be treated as a panacea for low election turnouts, whether this form of voting may be a warranty of a higher level of voter's attendance than before. In the article, the author bases on the experience connected with e voting in two European countries - Estonia and Switzerland, which can be referred to as the pioneers in the use of e voting.

\section{ELECTION TURNOUT AND THE METHODS OF INCREASING VOTERS' PARTICIPATION}

Over the last few decades, a number of countries throughout the world have witnessed a decline in the level of citizens' participation in national elections. According to the data of the International Institute for Democracy and Electoral Assistance (International IDEA), since the end of World War II till the mid seventies, presidential and parliamentary election attendance equalled some $75 \%$. Soon after that, the level fell below $70 \%$. Even more noticeable is the participation decrease in European Parliamentary elections where the average attendance fell from $65 \%$ within 1976-1990 to some 52\% in the following period. Table 1 demonstrates data concerning turnout in all national parliaments' elections and presidential elections in the world, as well as the European Parliamentary elections in the years 1945-2008. 
Table 1. Average turnout level in elections throughout the world (\%)

\begin{tabular}{|c|c|c|c|}
\hline \multirow{2}{*}{ Years } & \multicolumn{3}{|c|}{$\begin{array}{c}\text { Average turnout level in elections throughout the } \\
\text { world (\%) }\end{array}$} \\
\cline { 2 - 4 } & Parliamentary & Presidential & $\begin{array}{c}\text { European } \\
\text { Parliament }\end{array}$ \\
\hline $1945-1960$ & 77.4 & 74.7 & - \\
\hline $1961-1975$ & 76.7 & 78.6 & - \\
\hline $1976-1990$ & 75.9 & 74.5 & 64.9 \\
\hline $1991-2005$ & 69.9 & 69.5 & 51.7 \\
\hline $2006-2008$ & 66.6 & 68.7 & $-*$ \\
\hline
\end{tabular}

* No data - there were only data on two countries available.

Source: IDEA Votem Turnout Database, za: O. Pettersson, Rola instytucji publicznych $i$ organizacji pozarzadowych $w$ przekazywaniu obywatelom informacji o wyborach - przykłady działań z różnych krajów, International Institute for Democracy and Electoral Assistance (International IDEA), text prepared for seminar: „Jak skutecznie informować obywateli o wyborach?”, Instytut Spraw Publicznych, Warszawa, 19 June 2009, p. 4.

If elections attendance in numerous elections in the countries of Western Europe and Middle and Eastern Europe were compared, the indicator would surely be of advantage to the group of Western countries in Europe. A good example of that would be the European Parliamentary elections in 1979, which were of great interest among voters. At that time, the participation in the nine member countries equalled $61,99 \%$. Five, ten and fifteen years later, the average turnout level in all countries of the European Union was also remarkably high placing the level 57-58\%. In 1999, the participation level decreased to $49,51 \%$. Yet, the greatest change happened after the UE extension in 2004, when Central and Eastern countries of Europe joined the fifteen members of the UE. At that time the participation in the old member states equalled $37 \%$ to $90 \%$ and in the new, so called post-communist countries, the participation level was from $19 \%$ to $54 \%$.

Those results lead to a suggestion, that countries of the former Soviet bloc are far less active participants at election procedures, than those of Western Europe. Surely, it results from very different experiences concern- 
ing historical, political and social conditions in both parts of the Old Continent. It is worth emphasizing, that despite the citizens of Western Europe takeing part in elections more willingly, and in those countries, a fall in election turnout was noticed. A growing scepticism towards politicians and political institutions in general may have been observed in more recent, and a consequent decline in election participation, result in undertaking actions towards reversing those trends.

From the point of view of the above reflections, it is immensely important to suggest the most popular solutions that are used around the world and which may influence election participation level. The most frequent among these are:

- the institution of a plenipotentiary (a voter who cannot go to an election office in order to give a vote, can authorize another voter to give a vote in his/her name according to the instructions) ${ }^{3}$;

- voting by an authorized person (in this model a voter takes a package with election materials to the house of another voter and after he/she has voted, takes it back to the proper election committee)

- The institution of "the wondering ballot box" ("mobile ballot box") (provides the possibility of taking a special small ballot box to the house of a voter and voting there. This institution is directed mostly at the disabled, the elderly or the bed-ridden who cannot go to the polling station on their own';

- correspondence voting (prior to the day of elections, a voter receives a so-called election package with voting materials, that is a voting card, a return envelope and instructions on how to vote. In many countries it is aimed at those who are abroad) $)^{5}$;

- two-day voting (the period of voting is prolonged to two days);

- Voting in advance (allows giving a vote prior to the main election day in nominated polling stations. This solution is of great con-

3 This solution is working in the electoral system of France, Belgium and Great Britain.

4 This mechanism is functioning in Croatia, Czech Republic, Denmark, Lithuania, Latria and Ukraine.

5 This procedure is working in Austria, Belgium, Denmark, Finland, Spain, Ireland, Estonia, Lithuania, Great Britain, Germany, the United States, and from 2011 in Poland. 
venience for all those voters who, for a number of reasons, cannot be at the place of their residence on the day of elections $)^{6}$,

- information and promotion campaigns ${ }^{7}$;

- Obligatory voting (in some countries voting has been stated as obligatory, it is regulated in a principle act, or/and in elections acts. In some countries legislators expects some sanctions for those who omit elections) $)^{8}$.

\section{E VOTING AS A NEW FORM OF CITIZENS' PARTICIPATION IN POLITICAL LIFE}

One of the latest methods of increasing election turnout, and at the same time a new form of exercising power, is, so-called, electronic voting, which arouses growing interest of not only the governments and parliaments, but also of the voters themselves, who want to have more to say on the topic of political life. The use of modern technology in exercising democratic power, notably in the act of voting, is undoubtedly a new thing, not only from the perspective of public administration, but above all, from the electorate's point of view.

It is worth pointing out here, that voting based on electronic methods has a wide meaning and that Information and Communication Technology (ICT) techniques are used in the electoral system in three different ways. First of all, they are used in the process of gathering, elaborating and visualizing the results sent from election committees where voting takes

6 This solution is used for example in Estonia.

7 An important role in mobilization of voters play social campaigns. Such campaigns are mostly informational campaigns and are aimed at providing crucial information about the election: how, when and where to vote. The promotional campaigns concentrate on reasons of why to vote. Apolitical advertising campaigns are based on the belief that every vote counts and it may affect reality in the country. The organizers of these campaigns are also trying to remind voters that the civic duty and privilege is participation in elections.

8 Most of democratic governments recognize the participation in national elections as the citizen's right. Some, however, treat participation in elections as an expression of voters' civic responsibility. 
place in a traditional way, with voting cards. The second form of use is the new technology in the election process is electronically supported voting in which computer software is used as a tool to accept and count votes. The third area for the ICT to take place in the election process is remote voting via the Internet ${ }^{9}$.

Analyzing problems concerning the use of ICT in voting, it is noticeable that in literature on the subject matter, there is a peculiar disagreement as to the understanding of the term: electronic voting. The word $e$ voting is often identified as Internet voting or used interchangeably with this term. Meanwhile, electronic voting has a far wider meaning than Internet voting.

The essence of e-voting is voting with the use of electronic devices placed at polling stations or giving a vote outside a polling station (e.g. at a voter's house) with the use of the net, for instance the Internet. As a result, it must be noted, that the literature gives two kinds of such voting: electronic voting (e voting) and Internet voting (i voting). Electronic voting has a wider meaning and contains a form of Internet voting. E voting, in practice, refers to the use of, above all, television digital platforms, telephony and the Internet in the process of making election decision ${ }^{10}$. Internet voting can be divided into two categories: Internet Voting at the Polling Place and Remote Internet Voting. Internet Voting at the Polling Place is based on citizen vote given in a special place with the use of the Internet channel. Remote Internet Voting is a remote method of giving a vote, thanks to which, a voter votes from an election kiosk or from a domestic PC, which is linked to the Internet. Data from the two types of position is sent to the main database via the Internet.

Taking into account a method of voting where ICT tools are used, one may distinguish electronic elections and electronic referenda. From the technological point of view, the second method of voting seems to be less

9 Stanowisko Stowarzyszenia Internet Society Poland $w$ sprawie głosowania elektronicznego $w$ wyborach powszechnych przyjęte przez Zarząd Stowarzyszenia $w$ dniu 10 stycznia 2007 roku (uchwała Zarządu ISOC Polska nr 2/2007), 11.01.2007, Internet Society Poland, http://www.isoc.org.pl/200701/wybory, [26.06.2010].

10 M. Nowina-Konopka, Elektroniczna urna, http://www.rpo.gov.pl/pliki/1206605 8070.pdf, [27.11.2008]. 
complicated to implement, mostly because of the two possible answers in voting (Yes or No).

In order to define the term electronic referendum, one needs to explain two words constructing the term: referendum and electronic.

The idea of referendum is commonly associated with direct democracy and the followers of this institution claim that it poses a valid democratic tool, which enables mankind to decide directly about the important issues of a country.

In legal literature, referendum is defined as a "method of direct deciding by eligible people in the way of voting about essential matters of public life or of a given territory which is a subject of voting" ${ }^{11}$. According to Wolf Linder, one of the most famous researcher of Swiss direct democracy, referendum is "a constitutional law forcing the federal authorities to submit more important acts or treaties to popular voting" ${ }^{12}$. Making the most general definition, it must be stated that referendum is one of the forms of direct democracy, founded on the citizens' say on a given subject with the use of popular voting. Thus defined term, referendum is characterized by three factors:

- Direct citizens' participation in presenting their own opinion,

- Possessing only one vote by all of the voters,

- Recognizing the will of the majority as the basis for making a final decision in the process of legislating legal acts ${ }^{13}$.

The adjective electronic means those areas where means of electronic communications are used.

Electronic referendum (e-referendum) is, therefore, a form of voting on a given substance, in which citizens give votes not in a traditional way that is by the ballot boxes but with the use of ICT that is the Internet or digital telephone. Electronic referendum is normally an alternative method to voting in traditional referenda.

11 B. Banaszak, A. Preisner, Prawo konstytucyjne. Wprowadzenie, Wrocław 1996, p. 154

12 W. Linder, Demokracja szwajcarska Rozwiązywanie konfliktów w społeczeństwie wielokulturowym, Rzeszów 1996, p. 33.

13 M. Marczewska-Rytko, Demokracja bezpośrednia $w$ teorii i praktyce politycznej, Lublin 2001, p. 111. 
Summarizing, it is worthy to pay attention to the fact that the popularity of electronic voting increases mostly because it is a new, potentially more beneficial and convenient phenomenon for hundreds of millions of people in the entire world. In a number of European countries, attempts to introduce e voting have been undertaken for the last few years. Two such countries are Estonia and Switzerland. In both states, electronic (Internet) voting is used during public elections or referenda voting.

\section{E-ELECTIONS IN ESTONIA}

Estonia is one of the countries where the above forms of Remote Internet Voting have been introduced. In order to pass a vote via the Internet, the Estonian voter needs: a new generation ID, that is an electronic IDcard (eID card) with valid certificates (renewed on www sites), PIN codes (issued together with eID cards) and a computer equipped with an eID cards scanner (and proper software - installation on installer.id.ee/), connection with the net and the operation system Windows, MacOS or Linux $^{14}$.

Over the period from 2005 to 2009, Internet Voting with a binding result in Estonia was conducted four times. The first time voters had the opportunity to pass their votes over the net was in 2005 during elections to local authorities. Two years later voters took part in Internet elections to the Estonian Parliament. In 2009, the Estonians had the opportunity to vote over the net twice, first in June, in the second of this countres election to the European Parliament and in October during the election of the local authorities.

Research done on the use and effectiveness of $i$ voting in Estonia indicates that the Estonians' attitude towards the new form of voting at the beginning of implementing the e-voting system is positive. Taking advantage by the electorate of the use of the i-voting system is mostly dependent

14 Estonian National Electoral Committee, http://www.vvk.ee/index.php?id=11178\& $\mathrm{tpl}=1062,[10.10 .2010]$. 
on the trust of the new method, not, as had been feared earlier, on political influences.

It is essential to point out, that with each elections more and more of the Estonian electorate have used the Internet to pass their votes. Table 2 presents data concerning the final attendance in particular elections. It also provides information on the level of so-called i-turnout (that is votes given electronically in comparison to the number of all eligible to vote), and on the number of votes passed over the net and percentage of $i$-votes in comparison to all votes given.

Table 2. I-elections in Estonia - summary of selected data

\begin{tabular}{|l|c|c|c|c|}
\hline & $\begin{array}{c}\text { Local } \\
\text { elections } \\
\mathbf{1 0 . 2 0 0 5}\end{array}$ & $\begin{array}{c}\text { Parliamenta- } \\
\text { ry elections } \\
\mathbf{0 3 . 2 0 0 7}\end{array}$ & $\begin{array}{c}\text { Elections to the } \\
\text { European Par- } \\
\text { liament 06.2009 }\end{array}$ & $\begin{array}{c}\text { Local } \\
\text { elections } \\
\mathbf{1 0 . 2 0 0 9}\end{array}$ \\
\hline Turnout (\%) & $\mathbf{4 7 , 4 3}$ & $\mathbf{6 1 , 9 1}$ & 43,88 & 60,6 \\
\hline i-turnout (\%) & 0,91 & 3,46 & 6,54 & 9,74 \\
\hline Number of i-votes & 9681 & 31064 & 59579 & 106786 \\
\hline $\begin{array}{l}\text { Percentage of i-votes in the } \\
\text { total number of votes given (\%) }\end{array}$ & 1,85 & 5,44 & 14,68 & 15,74 \\
\hline
\end{tabular}

Source: author's own study based on data of Estonian National Electoral Committee.

As can be seen in chart 1, the level of Internet turnout ( i-votes number in comparison to the number of all eligible to vote) and percentage of $\mathrm{i}$-votes in a total number of all the votes given increases systematically. However, correlation between election attendance and i-voting indicators cannot be seen. Even if the turnout is lower than in the previous elections (just like in 2009 in comparison to the elections of 2007), the percentage of Internet votes is systematically growing.

In order to be able to form conclusions concerning the consequences of e-voting implementation for the level of the final election attendance, it is worth comparing the results of the two successive elections to the local government. Table 3 contains a detailed analysis of the results of local authorities in Estonia in October 2005 and 2009. 
Chart 1. I-elections in Estonia - summary of selected data in the period of time 2005-2009

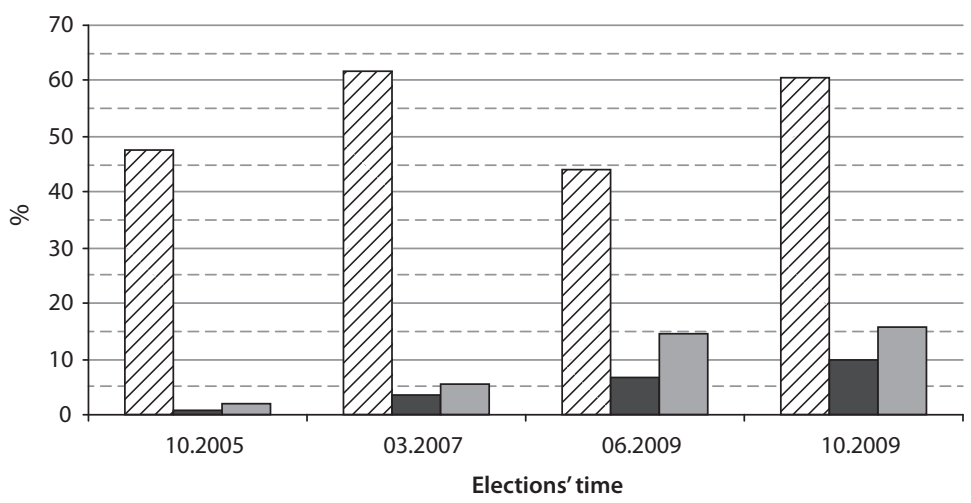

$\square$ Turnout $\square$ I-turnout $\square$ Percentage of i-votes in a total number of votes given

Source: author's own study based on data of Estonian National Electoral Committee.

Table 3. Local elections in Estonia in October 2005 and October 2009 - summary of data

\begin{tabular}{|l|c|c|}
\hline & $\begin{array}{c}\text { Local elections } \\
\text { of 2005 }\end{array}$ & $\begin{array}{c}\text { Local elections } \\
\text { of 2009 }\end{array}$ \\
\hline Number of citizens eligible to vote & 1059292 & 1094317 \\
\hline Number of votes given (i-votes included) & 502504 & 662816 \\
\hline Final turnout & $47,43 \%$ & $60,6 \%$ \\
\hline Number of i-votes & & \\
\hline Percentage od i-votes in a total number od votes given & $1,85 \%$ & 106786 \\
\hline i-turnout & $0,91 \%$ & $9,76 \%$ \\
\hline
\end{tabular}

Source: author's own study based on data of Estonian National Electoral Committee.

Comparing results of both elections, in 2009 an eightfold increase of the i-votes given (in total number of votes) can be observed. In 2005 the participation of $i$-votes in a total number of the votes given was $1,85 \%$, whereas four years later, in the fourth elections, which included the 
i-voting system, the same indicator reached a level of 15,74\%. Analyzing this sole indicator, one may pose a conclusion that there is great progress in the development of e-elections in Estonia, which is proved by the greater number of voters who decide to take part in election procedures with the use of the Internet ${ }^{15}$.

Summing up, it is essential to mention that Estonian authorities claim that Remote Internet Voting is a socially expected and accepted element of the election process in this country, which is crucial from the point of view of electorate involvement ${ }^{16}$. This is demonstrated in the data of the Estonian Election Committee - the turnout in parliamentary elections rose from $58,2 \%$ in 2004 to $61,9 \%$ in 2009 and in the European Parliamentary elections from $26,8 \%$ to $43 \%$, and $9 \%$ in $2009{ }^{17}$.

Moreover, the still greater participation of $\mathrm{i}$-votes in the structure of all of the votes given in elections is supported by the great level of trust of the Estonian public to the new election methods. We cannot, therefore be surprised by the fact that voters who decided to choose this kind of voting claim to have a slightly wider knowledge of computers and the Internet. As was emphasized in a Canadian report titled A Comparative Assessment of Electronic Voting, 20\% of i-voters in 2005 claimed that if they had not had the opportunity of i voting, most probably they would not have taken part in the elections at all. Still, in 2007, 11\% declared that if not for the possibility of $i$ voting they would most probably or surely not have voted in the elections. Therefore, the data suggests that the possibility of i voting can have an influence on society's involvement in elections, notably on those who normally do not take part in election procedures ${ }^{18}$.

15 Ü. Madise, P. Vinkel, E. Maaten, Internet Voting at the Elections of Local Government Councils on October 2005. Report, Estonian National Electoral Committee, http:// www.vvk.ee/public/dok/report2006.pdf, p. 28.

16 N. Goodman, J.H. Pammett, J. DeBardeleben, J. Freeland, A Comparative Assessment..., op.cit., p. 35.

17 Voter turnout data for Estonia, International Institute for Democracy and Electoral Assistance (International IDEA), http://www.idea.int/vt/country_view.cfm? country=EE, [1.12.2010]; Estonian National Electoral Committee, http://www.vvk.ee/, [1.12.2010].

18 N. Goodman, J.H. Pammett, J. DeBardeleben, J. Freeland, A Comparative Assessment..., op.cit., s. 35 . 


\section{E-REFERENDUM IN SWITZERLAND}

E voting is not only used in elections to legislative organs of the local or state level. A few countries have decided to make use of electronic methods of passing votes in direct democracy procedures, with special consideration for a referendum. Taking into account the number of countries, which used e voting in elections and referenda, it must be pointed out that the former is relatively bigger.

In Europe, electronic referendum has been used on a few occasions. One such example was a referendum in an Italian Ladispoli in September 2004, where some 25 thousand citizens were involved. In January 2005 another pilot e-referendum was conducted, this time in the Estonian city of Tallin ${ }^{19}$. It is worth noticing here, that in 2005 two other attempts were made to conduct e voting during referenda on ratification of the Treaty Legislating Constitution for Europe in Spain (where voting took place in February; remote i voting was used) and in France (where voting took place in May; special machines to vote were used).

Based on the above information one can state that the European experience with e-referenda is very limited. Actually, the only country that has been effectively using e-referenda is Switzerland, where since 2000 three electronic systems of voting have been conducted: Geneva E-voting System, Neuchâtel E-voting System, and Zurich E-voting System. All three systems are based on the use of ICT in voting procedures on local, cantonal and federal levels. Projects take into account a different scope for the use of modern technology. These enable the passing of votes from elections and referenda via the Internet, though in the earlier phases of the tests, voting via text messages were possible (Zurich E-voting System). The decision of

19 The authorities of Estonian capital and the National Electoral Commission held a vote among the population of Tallinn. Those eligible were asked about the location of the Monument of Freedom. In the referendum people could cast their vote in traditional voting booths, but also through the Internet. There were 703 given electronically; I-voting pilot in Tallinn, Estonian National Electoral Committee, http://www.vvk.ee/ public/dok/pilotdescription.txt, 28.06.2010; I-voting pilot in Tallinn. January 2005, Estonian National Electoral Committee, http://www.vvk.ee/public/dok/pilotresult_eng.pdf, [28.06.2010]. 
the legal introduction of e voting was first taken on a nationwide level, and then a decision was made on the level of particular cantons.

The project of the electronic voting system in the canton of Geneva is Remote Internet Voting. Its aim is, above all, to 'reach' all the Swiss living abroad $^{20}$ and the disabled.

The second electronic voting system Neuchâtel is also Remote Internet Voting, similar to the e-banking system. It was used for the first time in 2005 during a federal referendum on $25^{\text {th }}$ September ${ }^{21}$.

The electronic voting implementation project in Switzerland is supervised by the federal government, which for the time being poses restrictions on the cantons, which have already introduced an e-voting system. The Federal Council suggests that during federal elections not more than $10 \%$ of all the citizens of Switzerland should use this new tool of passing one's vote, which equals 500 thousand people. One should have in mind, that on the federal level the pilot phase was finished in 2007, and according to the situation in November 2009, the following cantons have already implemented electronic voting: Aargau, Basel-City, Fribourg, Geneva, Graubuenden/Grisons, Lucerne, Neuchâtel, Schaffhausen, Solothurn, St Gallen, Thurgau and Zurich.

The electronic voting project of the canton of Zurich, apart from the $i$ voting, enabled also the passing of votes with the use of a mobile phone (by sending a properly coded text message). Since the beginning of implementation of e-voting projects, pilot voting has occurred regularly on different occasions in Swiss cantons.

Table 4. Chosen electronic referendums in the time period of 2006-2008

\begin{tabular}{|l|l|c|c|c|}
\hline Time & Canton/Commune & $\begin{array}{c}\text { Number of } \\
\text { eligible voters }\end{array}$ & $\begin{array}{c}\text { Number of } \\
\text { e-votes }\end{array}$ & e-turnout \\
\hline 26.11 .2006 & Neuchâtel & 3554 & 1311 & $36.89 \%$ \\
\hline 26.11 .2006 & $\begin{array}{l}\text { Zurich: Bertschikon, } \\
\text { Bülach, Schlieren }\end{array}$ & 17344 & 1309 & $7.55 \%$ \\
\hline
\end{tabular}

20580000 Swiss citizens (1/10 of the population of the country) live abroad.

21 République et canton de Neuchâtel, www.ne.ch/gvu, [25.06.2009]. 


\begin{tabular}{|l|l|c|c|c|}
\hline Time & Canton/Commune & $\begin{array}{c}\text { Number of } \\
\text { eligible voters }\end{array}$ & $\begin{array}{c}\text { Number of } \\
\text { e-votes }\end{array}$ & e-turnout \\
\hline 11.03.2007 & Neuchâtel & 3757 & 1538 & $40.94 \%$ \\
\hline 17.06 .2007 & Neuchâtel & 4151 & 1494 & $35.99 \%$ \\
\hline 17.06 .2007 & $\begin{array}{l}\text { Zurich: Bertschikon, } \\
\text { Bülach, Schlieren }\end{array}$ & 17292 & 932 & $5.39 \%$ \\
\hline 24.02 .2008 & Neuchâtel & 4355 & 1516 & $34.81 \%$ \\
\hline 01.06 .2008 & Neuchâtel & 4705 & 1593 & $33.86 \%$ \\
\hline 01.06 .2008 & $\begin{array}{l}\text { Zurich: Bertschikon, } \\
\text { Bülach, Schlieren }\end{array}$ & 17777 & 1209 & $6.80 \%$ \\
\hline
\end{tabular}

Source: E-voting projects in Switzerland 2006-2008 and outlook, http://www.coe.int/t/e/ integrated_projects/democracy/Democracy_Forum_2008/Maurer_WS3.ppt, 15.12.2008.

Table 4 shows some of the e-referendums (the name i-referendum may also be used as the systems in Switzerland are based on the use of the Internet) which were conducted between the years $2006-2008$.

It can be seen that the electronic turnout, that is the participation of those who vote electronically in relation to all permitted to vote, is diversified: in the communes of the canton of Zurych reaching some 5-8\%, whereas in the canton of Neuchâtel 30-40\%. Similar results concerning e-turnout may be observed in the communes of Geneva canton. On average, more than $30 \%$ of those permitted to vote decided to vote via the electronic way. The data may suggest a relatively great number of the voters in the new methods of participation in voting and of the fact that the Swiss, who like to express their say in referenda, can choose more convenient ways of election participation. Hence probably, such a great interest, first in correspondence voting, and now in i voting.

Summarizing reflections on the three e-voting systems implemented in Switzerland one must pay attention to a few essential matters. Even though correspondence voting has increased election turnout, in some cases by more than several percent points, still e voting does not seem to have the same potential. E voting is an alternative for those who until now have been voting by post. According to data from the Zurich Statistical Office there is no strong evidence that e voting affects the final turnout in referenda. Of course, interest in e-voting increases, however, this trend is 
observed among those who usually or at least from time to time do participate in elections. Thus, the result is so that e voting is usually chosen by those who previously voted via post. One cannot therefore conclude that thanks to e voting in referendum a higher turnout is observed.

However, it is also important to notice that e voting may be attractive for those who have never voted or have done so rarely, and have knowledge and experience of using a PC. When someone chooses e voting, then during other elections will do the same. It is proved by research conducted by the Centre for Research on Direct Democracy (c2d), according to which, depending on the type and subject of voting, 12-15\% of those voting via the Internet define themselves as occasional voters or regular non-voters. $80 \%$ of them claim, that they would vote more often if i voting were more common. It must be conceded, that even though it is only an expression of willingness, it points to the potential of election turnout as a consequence of voting via the Internet. Thus, answering the question why Swiss authorities care so much about the implementation of e-voting, it can be stated that because of placing e-voting projects within the strategy of creating a more Information Technology conscious country, i-voting is an important social and political project. They provide easier access to the process of decision making, and not only those on a nationwide scale, but also on cantonal, commune and they can extend (although, there is no hard evidence to support that) the circle of citizenships involved in political life.

\section{CONCLUDING REMARKS}

Attention must be paid to the fact that in the context of the recently widely discussed crisis of the representative democracy, associated with, among other things, decreasing citizens' involvement in the process of political decision making, social and political life observers ask themselves the question about the solution of this problem and improving the condition of modern democracy. In the face of the development of modern technologies, more and more often one can observe tendencies connecting political spheres to the development of ICT. More and more often in 
a greater and greater number of countries, not only European ones, there appears information about initiatives which implement common electronic forms of voting. Those actions are motivated, among others, by the pursuit of increasing the election turnout. However, as the experience of Estonia and Switzerland shows us, there is no guarantee that e voting means an increase in the election participation level. Insofar as the project was a success in Estonia (from the perspective of voters' turnout), in Switzerland no significant change was noted in the common elections turnout. It is worth adding that the introduction of e voting with today's structure of the use of the Internet in many countries (e.g. Poland) would most probably result in disorder of the election statistics profile. Significant facilitation would gain better-educated, wealthier residents of large cities. To conclude these considerations, it is worth quoting the opinion of Edwin Bendyk, who finds that "experience of the nations, such as the US or France, where participation turnout has grown in recent years, shows that that revival was the result of the revival in the political sphere. The Internet has become the key device of political debate, enabling auto-expression to all who are interested"22.

22 E. Bendyk, Elektroniczne głosowanie - lek na całe zło?, 28.03.2008, Polityka.pl, http://www.polityka.pl/kraj/249743,1,elektroniczne-glosowanie-lek-na-cale-zlo.read? print=true, [29.12.2011]. 